\title{
WEAKNESSES OF THE NEGATIVE PUBLICATION SYSTEM WITH POSITIVE ELEMENTS IN AGRARIAN LAW IN INDONESIA
}

\author{
Suharyono $^{1}$
}

\begin{abstract}
In the negative publication system with positive elements in agrarian law in Indonesia at the implementation level, there are still a number of weaknesses, both weaknesses from the aspect of the norms for the purpose of land registration, aspects of legal responsibility and the system of imposing sanctions. There will be 3 (three) weaknesses in the Negative Publication System (positive elements) which are used as the basis for Land Registration by Government Regulation/PP Number 24 of 1997, namely: first; the norming system because it is imperative (norm imperative) and open (openbaar norm) which provides an opportunity for other parties to prove that they are the real owners of the land, thus resulting in legal disputes that must be resolved through the courts; second; the norm of legal responsibility for BPN/Kakan Land Officials who make mistakes in the implementation of land registration is not regulated in a negative publication system with positive elements, so that BPN/Land Office officials are not legally responsible when a certificate of land rights is canceled or declared invalid by a court decision; and third; norms and system for imposing sanctions for Land Registration Officers (BPN officials) who make mistakes in the implementation of land registration in Government Regulation/PP Number 24 of 1997 is not regulated.
\end{abstract}

Keywords: Negative Publications, Positive Elements, and Agrarian Law.

\section{The Introduction}

The problem with the negative publication system has positive elements used in the implementation of land registration, as regulated by Government Regulation no. 24 of 1997 concerning Land Registration, at the implementation level still leaves a number of weaknesses, both weaknesses from the aspect of norms for the purpose of land registration, aspects of legal responsibility and the system of imposing sanctions. In Law no. 5 of 1960 concerning Basic Regulations on Agrarian Principles (hereinafter abbreviated as UUPA) is a basic rule in the land sector and has been enforced nationally since September 24, 1960 is intended to replace regulations and decisions in the field of land inherited from the Dutch colonial, including Agrarische Wet Stb. 1870 N0. 55 and Agrarische Besluit Stb.1870 No. 118.

The legal provisions as mentioned above provide clarity on the purpose of the enactment of the LoGA, one of which is to provide legal certainty regarding land rights for the Indonesian people. In Urip Santoso's view that the guarantee of legal certainty regarding land rights for all Indonesian people as one of the objectives of the promulgation of the UUPA can be realized through two efforts, namely: first; the availability of written, complete and clear legal instruments that are carried out consistently in accordance with the spirit and provisions thereof. Second; implementation of land registration which is possible for holders of land rights to easily prove

1 The Lecturer of Law Magister of Universitas Muhammadiyah Palembang University and as the Suharyono \& Partners Advocate Jalan Angkatan 66 No. 594 Sekip Ujung Palembang, email; shy.lawfirm@gmail.com 
the rights to the land they control, and for interested parties, such as examples of buyers and prospective creditors, to obtain the necessary information regarding the land that is the object of the legal action to be carried out, and for the Government to implement land policies (Santoso, 2012: 277).

Urip Santoso's opinion above is in line with the provisions of Article 19 of the UUPA which states that land registration is an obligation for the government to implement it, aiming to provide legal certainty regarding land rights in order to bring prosperity, happiness and justice to the state and people, especially the peasants. for a just and prosperous society. The normative juridical provisions as regulated in Article 19 of the LoGA as well as Article 3 and Article 4 of PP. 24 of 1997 as mentioned above, basically confirms that the purpose of land registration is to provide legal certainty and legal protection to the holder of the right to a plot of land.

Observing the provisions of legal norms regarding the purpose of land registration in Article 19 of the LoGA and Article 3 of PP No. 24 of 1997 concerning Land Registration as mentioned above, the researcher can conclude that normatively the main objective of Land Registration is to provide legal certainty and legal protection to holders of rights to a plot of land. However, legal certainty and legal protection guaranteed through the implementation of land registration (as stipulated in Article 19 of the UUPA and Article 3 of PP No. 24 of 1997) do not have a safety valve regarding legal certainty, or explicitly said the value of legal certainty that has been guaranteed by Article 19 UUPA and Article 3 PP No. 24 of 1997 is countered by the provisions of the norms of article 32 PP. No. 24 of 1997, so that the right holder whose name is recorded in the land certificate is no longer guaranteed by law.

Legal certainty and legal protection are guaranteed, if before 5 (five) years from the date of registration of the land there is another party who submits an objection or submits a lawsuit to the court related to the implementation of the land registration that has been carried out and the objection or lawsuit can be resolved or won by the right holder. Legal certainty can also be achieved by the right holder, if after passing the time limit of 5 (five) years since the registration and issuance of the certificate of rights, no other party has filed an objection or a lawsuit regarding the registration of a parcel of land.

Observing the legal provisions that provide requirements regarding a time limit of 5 (five) years from the issuance of the certificate, the right for other parties to file an objection or lawsuit related to the issuance of the certificate as described above, raises the understanding that one day after the registration of a parcel of land and the issuance of products the law is called a certificate up to a time limit of 5 (five) years, then within that period the government in this case BPN is not responsible or disclaims its legal responsibility when there is a dispute or conflict or there are other parties who file objections and or lawsuits to the court, and the government is also not responsible for the actions taken by the certificate holder in using the certificate. So that the focus of the research is how are the weaknesses of the negative publication system with positive elements in agrarian law in Indonesia? 


\section{Research Methods}

While the research method uses normative (doctrinal) juridical research (Seomitro, 1994; 10-11) and non-doctrinal (Ibrahim, 2006; 443). Normative juridical (doctrinal) research was conducted to identify, interpret and explain the legal principles and concepts used to regulate land registration, especially those used as the basic framework in Law no. 5 of 1960 concerning Basic Regulations on Agrarian Principles, Government Regulation no. 24 of 1997 concerning Land Registration and Regulation of the Head of BPN No. 3 of 1997 concerning Provisions for the Implementation of PP No. 24 of 1997 concerning Land Registration. In connection with this research, the researcher uses inductive logic and deductive logic.

\section{Discussion and Results}

\section{Weaknesses of The Norms Setting Aspects in a Negative Publication System with Positive Elements}

The purpose of land registration in the negative publication system has positive elements that have been formulated in Article 3 and Article 4 of Government Regulation no. 24 of 1997, explicitly in its juridical norm is aimed at providing legal certainty and legal protection to the holders of rights to a plot of land. The provisions of the norms formulated in Articles 3 and 4 above, according to the researcher, are not in line with or collide with the juridical norms formulated by Article 32 paragraph (2) of Government Regulation no. 24 of 1997 which basically confirms that in the event that a certificate of legality has been issued on a parcel of land in the name of the person or legal entity that acquired the land in good faith and actually controls it, the other party who feels that he has rights to the land can no longer demand the exercise of the said right if within 5 (five) years from the issuance of the certificate, he does not file a written objection to the certificate holder and the Head of the Land Office concerned or does not file a lawsuit to the Court regarding the control of the land or the issuance of the certificate.However, in the negative publication system, the government does not guarantee the truth of the data presented, meaning that it does not provide legal certainty to people who are registered as rights holders (Wulansari, dkk, 2021: 65).

In a negative publication system, the legal action taken determines the transfer of rights to the buyer, not the registration. Registration does not make a person who acquires land from an unauthorized party the new right holder. In the negative publication system, the principle of nemo plus juris applies, namely that people cannot surrender or transfer rights beyond what they themselves have, therefore the state does not guarantee the truth of the data presented (Safitri, dkk, 2020: 790).

Observing the provisions of the juridical norms relating to the purpose of land registration above, in the view of the researcher that the purpose of land registration is not only to guarantee legal certainty and legal protection, it must also be understood that this goal is the purpose of land registration which has a conditional nature, so that the registration system Land can also be said to be a registration system that attaches guarantees of legal certainty and conditional legal protection.

This conditional nature can be seen in the juridical norm of Article 32 in the words that if within 5 (five) years from the issuance of the certificate 
there is no written objection to the certificate holder and the National Land Agency or submits a lawsuit to the court, then the purpose of land registration in the negative system is positive has not been correlated with the purpose of land registration which has been determined by Article 3 and Article 4 of Government Regulation no. 24 of 1997.

The issues surrounding the juridical norms in land registration as mentioned above, will obviously lead to conflicts and legal problems in the midst of society, both conflicts and legal conflicts between individuals, individuals with the community, individuals with the government, individuals with legal entities. private sector (company), community with community, community with private legal entity (company), community with government and private legal entity (company) with private legal entity (company) and private legal entity (company) with government.

\section{The Negative Publication System with Positive Elements has not Guaranteed Legal Certainty and Legal Protection in Relation to Land Registration}

General explanation of Government Regulation no. 24 of 1997 which explicitly states the purpose of land registration has also been explained in the Basic Agrarian Law (UUPA), that land registration is held in order to provide legal certainty in the land sector and the publication system is a negative system but contains positive elements., because it will produce letters of proof of rights that apply as strong evidence, as stated in Article 19 paragraph (2) letter c, Article 23 paragraph (2), Article 32 paragraph (2) and Article 38 paragraph (2) UUPA.

Basically, there are still differences of opinion in the application of Article 32 paragraph (2) of PP No. 24 of 1997, both from the public, theorists and legal practitioners. Based on the results of the research, this article contains two sides at once, namely, it cannot be separated from the positive side and the negative side. The positive side of norms in Article 32 paragraph (2) of PP No. 24 of 1997, can be explained below.

Article 32 paragraph (2) of PP Number 24 of 1997 can be said to implement the provisions contained in the LoGA, namely Articles 27, 34, and 40 of the LoGA. The reference used under this article is that land rights can be nullified due to neglect by the owner. With the implementation of Article 32 paragraph (2) PP Number 24 of 1997, the holder of land rights is obliged to physically control the plot of land and carry out a registration in order to avoid the possibility of having the land certificated in the name of another person.

Article 32 paragraph (2) of PP Number 24 of 1997 is considered to be able to cover the shortcomings of the negative registration system practiced by the Indonesian government. So, if the difference in the system lies in the strength between certificates as strong and absolute evidence, then this article can be used that certificates which were originally strong evidence can turn into absolute evidence, when the certificate has been registered and issued its rights have expired. five years, obtained in good faith and mastered in a real and open manner.

In such a position, it can be said that Article 32 paragraph (2) of PP Number 24 of 1997 is a legal step forward in the aspect of providing legal certainty for the community, in this case the rights they have. So that with 
this article, people who have land rights certificates feel safe and do not need to worry if there are problems with their land ownership in the future.

The application of Article 32 paragraph (2) of Government Regulation No. 24 of 1997 is also a motivation for land rights holders to register their land with the Land Office. Community awareness in this regard will be further increased because they can feel the practical benefits that their rights to their land will not be disputed by other parties who feel that they have the same land with a certificate that they obtained in good faith, owned for more than five years and the land controlled in a real and open manner.

Article 32 paragraph (2) of PP Number: 24 of 1997 is an application of the jurisprudence of court decisions based on the concept of rechtverwerking which has been used many times by judges in resolving disputes over customary lands in Indonesia, so Article 32 paragraph (2) of PP Number 24 of 1997 should also be applied by judges in resolving land registration disputes in Indonesia today. (Effendy, 2014; 87).

The negative side of the application of Article 32 paragraph (2) of PP Number 24 of 1997, among others, contradicts Article 19 of the LoGA, that a certificate is a strong (not absolute) evidence so that a lawsuit is still possible against it as long as it can be proven by another party. In Article 32 paragraph (2) of PP Number 24 of 1997, the certificate of land rights after more than 5 (five) years has passed since it was issued, as a strong proof of ownership it will turn into absolute evidence. So, in this case there is a conflict between the legal norms regulated in the Basic Agrarian Law and Government Regulation no. 24 of 1997 where the position of the Act is higher than the Government Regulation, so there is an assumption that Article 32 paragraph (2) of PP Number 24 of 1997 cannot be applied in resolving land disputes.

In addition to contradicting the registration system which questions the strength of certificate proof, Article 32 paragraph (2) of Government Regulation No. 24 of 1997 also contradicts the principle used in the negative publication system, namely the principle of nemo plus juris, whereas Article 32 paragraph (2) of Government Regulation No. 24 of 19971997 refers to the principle of good faith, where the principle of good faith is used in the positive registration system. So it is feared that there will be conflicts and overlapping of legal rules.

Furthermore, Article 32 paragraph (2) of PP Number 24 of 1997 has also limited the rights of a person or legal entity in demanding the implementation of their rights. This is clearly detrimental to the actual land owners because they no longer have the right to claim their land. For example, if the other party as the actual owner has strong evidence in the eyes of the law that he is the real owner of the land, but the filing of a lawsuit as a legal step to reclaim the rights to the land cannot be done because the five-year period since the issuance of the certificate has passed.

Another weakness is, under such conditions it is feared that it will bring injustice. The application of Article 32 paragraph (2) of PP Number 24 of 1997 will harm the actual land owner, if the acquisition of the land is actually illegal or not in good faith or if the court cannot prove that the acquisition of the land was not in good faith even though the actual acquisition was on the land is illegitimate. This is because the existence of 
will is a proof that is difficult to do. So that it will clearly harm the actual right owner, because there is no compensation for the injured party.

Basically, the author agrees with the implementation of Article 32 paragraph (2) of PP No. 24 of 1997 on the condition that in the issuance of the certificate of land rights, the parties related to the issuance both in providing instructions as a condition for the issuance of the certificate and in the process of issuing it are correct. -truly based on honesty and thoroughness.

The application of the above provisions will return to the purpose of land registration in the UUPA and the needs of the Indonesian people, namely to provide legal certainty in the land sector, meaning that by registering, the ownership of a plot of land can no longer be disturbed by other parties who feel they have ownership. the same land he owns. If the implementation of land registration in Indonesia goes well, it means that the community is well aware that the land they own must be registered so that a certificate of land rights will be obtained. Parties related to the implementation of land registration, both the kelurahan in terms of issuing letters/documents as a condition for land registration and the Land Office in terms of issuing certificates through the proper process and in the best possible way so that lands in Indonesia are indeed registered in the name of a person who is truly entitled, then Article 32 paragraph (2) of PP Number 24 of 1997 should be an article in the law, not in a government regulation which is hierarchically under the law. This is in accordance with the purpose of carrying out land registration, namely to provide legal certainty and legal protection to holders of land rights so that they can easily prove themselves as holders of the rights in question.

At the level of implementation, until now there has been no agreement between the judges regarding the application of Article 32 paragraph (2) of PP No. 24 of 1997. The application of this article still depends on the judge's consideration whether it will bring justice to the disputing parties.

There are two conflicting interests, namely if the Plaintiff is really the owner of the actual land rights and the Defendant actually obtained his land rights in good faith, so whether or not this article is applied to the settlement of land disputes is in the authority of the judge who hears the case.

The existence of this article is not yet binding on judges in deciding cases but in essence the existence of this article is to call attention to the Court, especially judges who decide disputes that there is a rechtverwerking concept, namely the original concept of this Article which has been applied many times by the Supreme Court, namely if If a person controls the land in good faith, it is actually controlled and no one raises an objection for a certain period of time, the objection will not be accepted.

Opinions of legal theorists regarding the existence of Article 32 paragraph (2) of PP No. 24 of 1997, until now there are still differences. Generally, theorists who agree consider that the existence of this article is an application of customary law and this article is a guarantee of legal certainty for certificate holders while theorists who disagree consider that this article is not an application of customary law, but an application of Dutch law which is not suitable if applied. in Indonesia because it is not in accordance with the spirit of the UUPA and it is feared that it will bring injustice to the people of Indonesia (Maladi, 2012; 56). 
Generally, practitioners who are directly related to the resolution of legal problems, namely judges and lawyers, do not agree with the application of this article, for fear of causing injustice. This is because the actual owner of the right can lose the right he actually has. Meanwhile, people who have certificates and legal practitioners related to land registration directly, namely Land Deed Maker Officials and Land Office Officials agree with the implementation of this article because it guarantees protection and legal certainty for those who have registered their rights in accordance with the purpose of land registration.

\section{Weaknesses of the Aspect of Regulation of Legal Responsibilities of BPN/Land Office Officials in a Negative Publication System with Positive Elements}

As an initial introduction related to the issue of legal responsibility regulatory aspects, this dissertation focuses on authority and responsibility, which are two things that are difficult to separate from one another. Every authority is always possible to be juxtaposed with legal responsibilities both theoretically and in juridical practice. In other words, authority always has legal consequences that are closely related to responsibility.

The discussion about legal responsibility is the most important part in every act / action taken by every state administrator, including actions / actions in the field of issuing land certificates within the BPN / Land Office. In connection with the problems mentioned above, in this chapter the juridical normative research will be conducted and it will be explained whether the negative publication system has positive elements normatively regulating the legal responsibility system if the certificate product issued by the BPN / Land Office is canceled or declared invalid by a decision. court, what are the legal responsibilities of BPN / Land Office officials to rights holders, actual owners and third parties.

The concept of responsibility provides an understanding that every act that is not good to others, including bad actions committed by the government must be legally and politically accountable. If this responsibility falls within the realm of law, then the government's responsibility as above must be understood as a legal responsibility (Fuadi, 2011; 147).

The government's responsibility to its people appears in two theories, namely the theory of common law and the theory of democracy. In general law theory requires that every legal subject, person and government must be held accountable for their actions because of an error (strict liability) or not (Judge, 20121 43).

The existence of errors/omissions or not, for every government action becomes the basis for the emergence of legal responsibility both in the criminal aspect, civil aspect and legal responsibility in the administrative aspect. This is a consequence of Indonesia as a legal state which requires that all actions or actions of the authorities have a clear legal basis or have legality, both based on written law and unwritten law (Harahap, 1997; 1).

Promoting the rule of law is the most rational choice in order to prevent these deviations from occurring. In short, it can be said that all government activities must remain under adequate control. The existence of a government that is always under supervision means that the government must comply with the rule of law (Erwiningsih, 72). 
In order to guarantee and provide a legal basis that government actions (bestuurhendeling) carried out by the government as a legal act (legitimate and justified), accountable and responsible, then every government action must be based on on a just, dignified and democratic law as a consequence of Indonesia as a state of law.

The effectiveness of the process of using power that is subject to the law, will ultimately become a work assessment for government officials and agencies including the national land agency/land office, therefore in order for legal norms to run effectively and efficiently, it is necessary to observe several criteria that seem to be used as parameters. adequate for laws that have a high level of enforcement. If the level of law enforcement increases sharply/highly, this indicates a high level of awareness of the law community.

Some of these criteria are as follows: Necessity, that the law must be formulated in accordance with systematic and planned needs; Adequacy, that the formulation of legal norms must have a high level and degree of certainty; Legal Certainty, that the law must have a high level of legal certainty; Clearly, that the law must really contain clear and real rules, not be vague and not cause interpretation; Actuality, that the law must be able to adapt to the development of society and the times, without ignoring legal certainty; Feasibility, that the law must have a justifiable feasibility, especially with regard to the level of arrangement; Verifiability, that the law that is framed must be in a condition that is ready to be tested objectively; Enforceability, that the law in essence continues to have the power of coercion to be obeyed and respected; Provability, that the law must be made in such a way that it is easy to prove (Safi, 2010; 174).

The fundamental issue of the laws and regulations governing rights specifically related to land issues within the framework of guaranteeing legal certainty as stated in Article 3 of Government Regulation no. 24 of 1997 concerning Land Registration, according to the researcher, has not reflected the guarantee of fair legal certainty as required by the 1945 Constitution of the Republic of Indonesia which is correlated with the fifth principle of Pancasila, namely social justice for all Indonesian people (Kaelan, 2013; 125)

Related to the problem above, in the thinking of the positivists more emphasis on legal certainty, while the functionalists prioritize the benefits of law, and if it can be stated that "summum ius, summa injuria, summa lex, summa crux" which means that harsh laws can hurt, except justice which can help him, thus even though justice is not the sole goal of law, the most substantive goal of law is justice (Rato, 2010; 59).

So far, the teaching of legal certainty comes from juridical-dogmatic teachings based on the positivist school of thought in the legal world, which tends to see law as something autonomous, independent, because for adherents of this thought, law is nothing but a collection of rules. For adherents of this school, the purpose of law is nothing but guaranteeing the realization of legal certainty.

Legal certainty is realized by law with its nature which only makes a general rule of law. The general nature of the rule of law proves that the law does not aim to achieve justice or benefit, but solely for certainty (Ali, 2002; 82-830). Thus, the legal certainty contained in Government Regulation no. 24 of 1997 concerning land registration is not in line or in the same breath with fair legal certainty according to the 1945 Constitution and Pancasila. 
As with the policy of imposing sanctions on BPN / Kakan Land officials who are proven to have committed acts of maladministration, criminal acts and unlawful acts can be explained in the description below. The focus of the description below specifically describes the imposition of sanctions on BPN / Kakan Pertanahan officials who commit acts of maladministration, criminal acts or acts against the law.

Normatively, the provisions of sanctions that can be imposed on BPN / Kakan Pertanahan officials who are proven to have committed maladministration can be subject to sanctions as shown in table I below.

\section{Table I}

Provisions for Sanctions That Can Be Implemented by Sanctions To Bpn / Kakan Agrarian Officials

\begin{tabular}{|c|c|c|c|}
\hline No & Rule of law & The Norm of Law & Sanction \\
\hline & $\begin{array}{ll}\text { Article } \quad 11 \\
\text { Paragraph (2) }\end{array}$ & $\begin{array}{l}\text { Organizers are required to give awards to } \\
\text { Executors who have work performance. }\end{array}$ & \multirow{13}{*}{$\begin{array}{l}\text { Written } \\
\text { warning. }\end{array}$} \\
\hline & $\begin{array}{l}\text { Article11 } \\
\text { Paragraph }(3)\end{array}$ & $\begin{array}{l}\text { The organizer is obliged to give punishment to } \\
\text { the implementer who violates the internal } \\
\text { provisions of the organizer. }\end{array}$ & \\
\hline & $\begin{array}{l}\text { Article15 } \\
\text { letter e }\end{array}$ & $\begin{array}{l}\text { Provide quality services in accordance with } \\
\text { the principles of public service delivery; }\end{array}$ & \\
\hline & $\begin{array}{l}\text { Article17 } \\
\text { letterg }\end{array}$ & $\begin{array}{l}\text { Actively participate and comply with laws and } \\
\text { regulations related to the implementation of } \\
\text { public services; }\end{array}$ & \\
\hline & $\begin{array}{l}\text { Article10 } \\
\text { Paragraph(1) }\end{array}$ & $\begin{array}{l}\text { The Operator is obliged to carry out } \\
\text { evaluations of the performance of the } \\
\text { Executor within the organization on a regular } \\
\text { and continuous basis. }\end{array}$ & \\
\hline & $\begin{array}{l}\text { Article10 } \\
\text { Paragraph (2) }\end{array}$ & $\begin{array}{l}\text { Based on the results of the evaluation as } \\
\text { referred to in paragraph (1), the Operator is } \\
\text { obliged to make efforts to increase the } \\
\text { capacity of the Executor. }\end{array}$ & \\
\hline & $\begin{array}{l}\text { Article13 } \\
\text { Paragraph(1) } \\
\text { letter b }\end{array}$ & $\begin{array}{l}\text { the organizer is obliged to inform the public of } \\
\text { the cooperation agreement; }\end{array}$ & \\
\hline & $\begin{array}{l}\text { Article13 } \\
\text { Paragraph (1) } \\
\text { letter e }\end{array}$ & $\begin{array}{l}\text { Operators and other parties are required to } \\
\text { include the address of the place to complain } \\
\text { and the facilities to accommodate public } \\
\text { complaints that are easily accessible, } \\
\text { including telephone, short message service } \\
\text { (sms), website (website), e-mail (e-mail), and } \\
\text { complaint box. }\end{array}$ & \\
\hline & $\begin{array}{l}\text { Article15 } \\
\text { letter e }\end{array}$ & $\begin{array}{l}\text { provide quality services in accordance with } \\
\text { the principles of public service delivery; }\end{array}$ & \\
\hline & $\begin{array}{l}\text { Article15 } \\
\text { letter f }\end{array}$ & $\begin{array}{l}\text { carry out services in accordance with service } \\
\text { standards; }\end{array}$ & \\
\hline & $\begin{array}{l}\text { Article16 } \\
\text { letter a }\end{array}$ & $\begin{array}{l}\text { perform service activities in accordance with } \\
\text { the assignment given by the Operator; }\end{array}$ & \\
\hline & $\begin{array}{l}\text { Article } 17 \\
\text { letter b }\end{array}$ & $\begin{array}{l}\text { Leave your duties and obligations, unless you } \\
\text { have clear, rational, and legitimate reasons in } \\
\text { accordance with the laws and regulations; }\end{array}$ & \\
\hline & $\begin{array}{l}\text { Article17 } \\
\text { letter c }\end{array}$ & $\begin{array}{l}\text { Add executors without the operator's } \\
\text { approval; }\end{array}$ & \\
\hline
\end{tabular}




\begin{tabular}{|l|l|l|}
\hline Article 25 & $\begin{array}{l}\text { The Implementer is required to provide a } \\
\text { report to the Operator regarding the } \\
\text { conditions and needs of facilities, } \\
\text { infrastructure, and/or public service facilities } \\
\text { as well as the Executor in accordance with the } \\
\text { demands for service standard requirements. }\end{array}$ \\
\hline Article 29 (2) & $\begin{array}{l}\text { Facilities, infrastructure, and/or public service } \\
\text { facilities with special treatment as referred to } \\
\text { in paragraph (1) are prohibited from being } \\
\text { used by unauthorized persons. }\end{array}$ \\
\hline $\begin{array}{l}\text { Article44 } \\
\text { Paragraph (1) }\end{array}$ & $\begin{array}{l}\text { The organizer and/or ombudsman must } \\
\text { provide a receipt }\end{array}$ \\
\hline
\end{tabular}

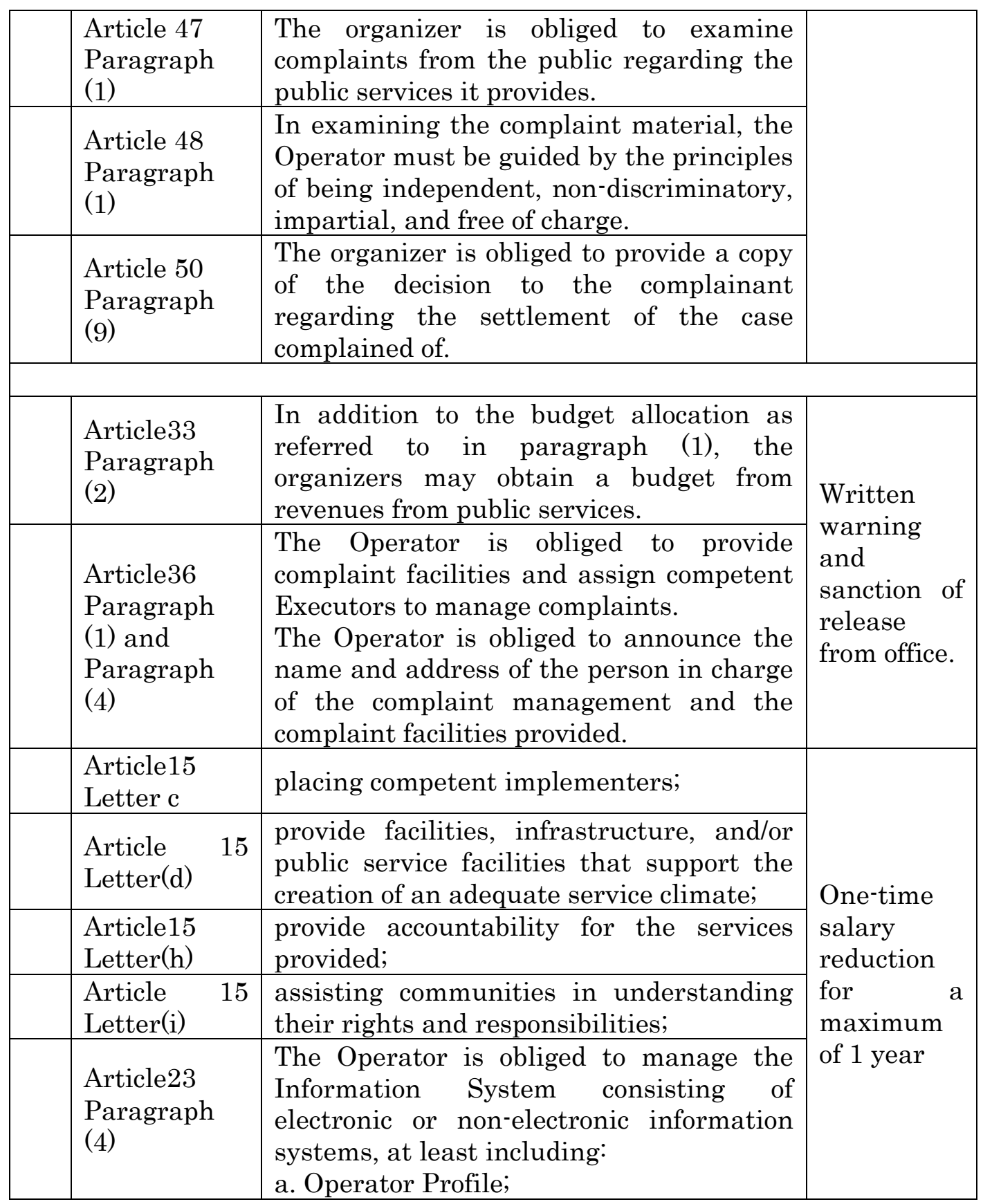




\begin{tabular}{|l|l|l|}
\hline & $\begin{array}{l}\text { b. Implementing Profile; } \\
\text { c. Service standard; } \\
\text { d. Service notices; } \\
\text { e. Complaint management; and } \\
\text { f. Performance assessment. }\end{array}$ \\
\hline $\begin{array}{l}\text { Article23 } \\
\text { Paragraph } \\
(5)\end{array}$ & $\begin{array}{l}\text { The Operator is obliged to provide the } \\
\text { information as referred to in paragraph } \\
\text { (4) to the public in an open and easily } \\
\text { accessible manner. }\end{array}$ \\
\hline
\end{tabular}

\begin{tabular}{|c|c|}
\hline $\begin{array}{l}\text { Article } \\
25 \\
\text { Paragrap } \\
\text { h (1) }\end{array}$ & $\begin{array}{l}\text { The organizers and implementers are obliged } \\
\text { to manage the facilities, infrastructure, } \\
\text { and/or public service facilities in an effective, } \\
\text { efficient, transparent, accountable, and } \\
\text { sustainable manner and are responsible for } \\
\text { the maintenance and/or replacement of public } \\
\text { service facilities, infrastructure, and/or } \\
\text { facilities. }\end{array}$ \\
\hline $\begin{array}{l}\text { Article } \\
28 \\
\text { Paragrap } \\
\text { h(1) }\end{array}$ & $\begin{array}{l}\text { Operators who intend to repair facilities, } \\
\text { infrastructure, and/or public service facilities } \\
\text { are required to announce and state the } \\
\text { deadline for completing the work in a clear } \\
\text { and open manner. }\end{array}$ \\
\hline $\begin{array}{l}\text { Article } \\
28 \\
\text { Paragrap } \\
\text { h (2) }\end{array}$ & $\begin{array}{l}\text { The repair of public service facilities, } \\
\text { infrastructure, and/or facilities as referred to } \\
\text { in paragraph (1) is prohibited from causing } \\
\text { the cessation of public service activities. }\end{array}$ \\
\hline $\begin{array}{l}\text { Article } \\
29 \\
\text { Paragrap } \\
\text { h(1) }\end{array}$ & $\begin{array}{l}\text { The organizer is obliged to provide services } \\
\text { with special treatment to certain community } \\
\text { members in accordance with the laws and } \\
\text { regulations. }\end{array}$ \\
\hline $\begin{array}{l}\text { Article } \\
36 \\
\text { Paragrap } \\
\text { h (2) }\end{array}$ & $\begin{array}{l}\text { The organizer is obliged to manage } \\
\text { complaints originating from service } \\
\text { recipients, recommendations from the } \\
\text { ombudsman, the People's Representative } \\
\text { Council, the Provincial DPRD, and the } \\
\text { Regency/City Regional People's } \\
\text { Representative Council within a certain time } \\
\text { limit. }\end{array}$ \\
\hline $\begin{array}{l}\text { Article } \\
37 \\
\text { Paragrap } \\
\text { h (1) }\end{array}$ & $\begin{array}{l}\text { The operator is obliged to develop a } \\
\text { mechanism for managing complaints from } \\
\text { service recipients by prioritizing the principle } \\
\text { of quick and complete settlement. }\end{array}$ \\
\hline $\begin{array}{l}\text { Article } \\
43 \\
\text { Paragrap } \\
\text { h (2) }\end{array}$ & $\begin{array}{l}\text { In the event that the complainant requires } \\
\text { documents related to his complaint from the } \\
\text { organizer and/or executor to support the } \\
\text { evidence as referred to in paragraph (1), the } \\
\text { organizer and/or executor must provide it. }\end{array}$ \\
\hline Article & The organizer and/or ombudsman must \\
\hline
\end{tabular}




\begin{tabular}{|l|l|l|}
\hline $\begin{array}{l}\text { Paragrap } \\
\mathrm{h}(3)\end{array}$ & $\begin{array}{l}\text { respond to public complaints no later than 14 } \\
\text { (fourteen) days after the complaint is received } \\
\text { which at least contains complete or } \\
\text { incomplete information on the complaint } \\
\text { material as referred to in Article 42 } \\
\text { paragraph (3). }\end{array}$ \\
\hline $\begin{array}{l}\text { Article } \\
50\end{array}$ & $\begin{array}{l}\text { The decision as referred to in paragraph (1) } \\
\text { must be submitted to the complainant no } \\
\text { Paragrap } \\
\mathrm{h}(2)\end{array}$ & $\begin{array}{l}\text { later than 14 (fourteen) days after the } \\
\text { decision is made. }\end{array}$ \\
\hline
\end{tabular}

\begin{tabular}{|c|c|c|}
\hline $\begin{array}{l}\text { Article } 38 \\
\text { Paragraph(1) }\end{array}$ & $\begin{array}{l}\text { Operators are obliged to periodically } \\
\text { evaluate the performance of public service } \\
\text { delivery. }\end{array}$ & $\begin{array}{l}\text { Demotion at } \\
\text { a lower level } \\
\text { for a } \\
\text { maximum of } \\
1 \text { (one) year. }\end{array}$ \\
\hline $\begin{array}{l}\text { Article } 11 \\
\text { Paragraph (1) }\end{array}$ & $\begin{array}{l}\text { The Organizer is obliged to conduct the } \\
\text { selection and promotion of Executors in a } \\
\text { transparent, non-discriminatory, and fair } \\
\text { manner in accordance with the laws and } \\
\text { regulations. }\end{array}$ & \multirow{8}{*}{$\begin{array}{l}\text { sanctions } \\
\text { for release } \\
\text { from office. }\end{array}$} \\
\hline $\begin{array}{l}\text { Article } \\
\text { letterc }\end{array}$ & $\begin{array}{l}\text { fulfill a summons to attend or carry out an } \\
\text { order for a legal action at the request of an } \\
\text { authorized official from a state institution or } \\
\text { government agency that is entitled, } \\
\text { authorized, and legally in accordance with } \\
\text { the laws and regulations; }\end{array}$ & \\
\hline $\begin{array}{l}\text { Article } \\
\text { letter d, }\end{array}$ & $\begin{array}{l}\text { provide accountability when resigning or } \\
\text { relinquishing responsibility in accordance } \\
\text { with the laws and regulations; and }\end{array}$ & \\
\hline $\begin{array}{l}\text { Article } \\
\text { lettere, }\end{array}$ & $\begin{array}{l}\text { evaluate and make financial and } \\
\text { performance reports to the Operator on a } \\
\text { regular basis. }\end{array}$ & \\
\hline $\begin{array}{l}\text { Article } \\
\text { lettera }\end{array}$ & $\begin{array}{l}\text { Concurrently serving as commissioner or } \\
\text { administrator of business organizations for } \\
\text { implementers from government agencies, } \\
\text { state-owned enterprises, and regionally- } \\
\text { owned enterprises }\end{array}$ & \\
\hline $\begin{array}{ll}\text { Pasal } & 17 \\
\text { letter d, } & \end{array}$ & $\begin{array}{l}\text { Add executors without the operator's } \\
\text { approval; }\end{array}$ & \\
\hline $\begin{array}{l}\text { Article } 20 \\
\text { Paragraph(2) }\end{array}$ & $\begin{array}{l}\text { In compiling and setting service standards as } \\
\text { referred to in paragraph ( } 1 \text {, the Operator is } \\
\text { obliged to involve the public and related } \\
\text { parties. }\end{array}$ & \\
\hline $\begin{array}{l}\text { Article } 20 \\
\text { Paragraph (3) }\end{array}$ & $\begin{array}{l}\text { The Operator is obliged to implement the } \\
\text { service standard as referred to in paragraph } \\
\text { (1). The participation of the community and } \\
\text { related parties as referred to in paragraph } \\
\text { (2) is carried out on the principle of non- } \\
\text { discrimination, is directly related to the type }\end{array}$ & \\
\hline
\end{tabular}


of service, has competence and prioritizes

deliberation, and pays attention to diversity.

\begin{tabular}{|c|c|}
\hline Article22 & $\begin{array}{l}\text { (1) (1) The Operator is obliged to compile and } \\
\text { stipulate a service announcement which is } \\
\text { a statement of the Provider's ability to } \\
\text { carry out services in accordance with the } \\
\text { service standards as referred to in Article } \\
21 \text {. } \\
\text { (2) The notice of service as referred to in } \\
\text { paragraph (1) must be published clearly } \\
\text { and widely. }\end{array}$ \\
\hline $\begin{array}{l}\text { Article } 28 \\
\text { Paragraph(4) }\end{array}$ & $\begin{array}{l}\text { The Operators and Executors who do not } \\
\text { perform the obligations as referred to in } \\
\text { paragraph (1) are declared to have } \\
\text { committed negligence. }\end{array}$ \\
\hline $\begin{array}{l}\text { Article33 } \\
\text { Paragraph (1) }\end{array}$ & $\begin{array}{l}\text { The cost/tariff for public services is basically } \\
\text { the responsibility of the state and/or the } \\
\text { community. }\end{array}$ \\
\hline $\begin{array}{l}\text { Article } 36 \\
\text { Paragraph (3) }\end{array}$ & $\begin{array}{l}\text { The Operator is obliged to follow up on the } \\
\text { results of the complaint management as } \\
\text { referred to in paragraph (2). }\end{array}$ \\
\hline $\begin{array}{l}\text { Article } 48 \\
\text { Paragraph (2) }\end{array}$ & $\begin{array}{l}\text { Operators are required to receive and } \\
\text { respond to complaints. }\end{array}$ \\
\hline $\begin{array}{l}\text { Article50 } \\
\text { Paragraph (1) }\end{array}$ & $\begin{array}{l}\text { The organizer is obliged to decide on the } \\
\text { results of the complaint examination no later } \\
\text { than } 60 \text { (sixty) days after the complaint file } \\
\text { is declared complete. }\end{array}$ \\
\hline $\begin{array}{l}\text { Article50 } \\
\text { ayat }(4)\end{array}$ & $\begin{array}{l}\text { The organizer is obliged to provide a budget } \\
\text { to pay compensation. }\end{array}$ \\
\hline $\begin{array}{ll}\text { Article } & 15 \\
\text { letter a } & \end{array}$ & compiling and setting service standards; \\
\hline $\begin{array}{ll}\text { Article } & 15 \\
\text { letterb }\end{array}$ & $\begin{array}{l}\text { compose, determine, and publish service } \\
\text { notices; }\end{array}$ \\
\hline $\begin{array}{l}\text { Article15 } \\
\text { lettere }\end{array}$ & $\begin{array}{l}\text { provide quality services in accordance with } \\
\text { the principles of public service delivery; }\end{array}$ \\
\hline $\begin{array}{l}\text { Article15 } \\
\text { letter j }\end{array}$ & $\begin{array}{l}\text { assist communities in understanding their } \\
\text { rights and responsibilities; }\end{array}$ \\
\hline $\begin{array}{l}\text { Article15 } \\
\text { letter } \mathrm{k}\end{array}$ & $\begin{array}{l}\text { provide accountability in accordance with } \\
\text { applicable law when resigning or } \\
\text { relinquishing responsibility for a position or } \\
\text { position; and }\end{array}$ \\
\hline $\begin{array}{l}\text { Article15 } \\
\text { letter l }\end{array}$ & $\begin{array}{l}\text { fulfill a summons or represent an } \\
\text { organization to attend or carry out an order } \\
\text { for a legal action at the request of an } \\
\text { authorized official from a state institution or } \\
\text { government agency that is entitled, } \\
\text { authorized, and legally in accordance with } \\
\text { the laws and regulations. }\end{array}$ \\
\hline
\end{tabular}




\begin{tabular}{|c|c|c|}
\hline $\begin{array}{l}\text { Article } 20 \\
\text { Paragraph (1) }\end{array}$ & $\begin{array}{l}\text { The Operator is obliged to formulate and } \\
\text { determine service standards by taking into } \\
\text { account the capabilities of the Operator, the } \\
\text { needs of the community, and environmental } \\
\text { conditions. }\end{array}$ & \multirow{3}{*}{$\begin{array}{l}\text { Dismissal } \\
\text { with honor } \\
\text { is not at his } \\
\text { own } \\
\text { request. }\end{array}$} \\
\hline Article26 & $\begin{array}{l}\text { Operators are prohibited from granting } \\
\text { permits and/or allowing other parties to use } \\
\text { public service facilities, infrastructure, } \\
\text { and/or facilities which result in public service } \\
\text { facilities, infrastructure and/or facilities not } \\
\text { functioning or not in accordance with their } \\
\text { designation. }\end{array}$ & \\
\hline $\begin{array}{l}\text { Article33 } \\
\text { Paragraph(3) }\end{array}$ & $\begin{array}{l}\text { Operators are prohibited from financing } \\
\text { other activities using budget allocations } \\
\text { intended for public services. }\end{array}$ & \\
\hline $\begin{array}{l}\text { Article27 } \\
\text { Paragraph (1) }\end{array}$ & $\begin{array}{l}\text { Shares of organizers in the form of state- } \\
\text { owned enterprises and regional-owned } \\
\text { enterprises related to public services are } \\
\text { prohibited from being transferred under any } \\
\text { circumstances, either directly or indirectly } \\
\text { through sales, guarantees or other matters } \\
\text { that result in the transfer of power to run the } \\
\text { corporation or loss of rights. become the } \\
\text { property of the corporation as regulated in } \\
\text { the laws and regulations. }\end{array}$ & \multirow[t]{2}{*}{$\begin{array}{l}\text { Dismissal } \\
\text { without } \\
\text { respect }\end{array}$} \\
\hline $\begin{array}{l}\text { Article49 } \\
\text { Paragraph(1) }\end{array}$ & $\begin{array}{l}\text { In examining the complaint material, the } \\
\text { Operator is required to maintain } \\
\text { confidentiality. }\end{array}$ & \\
\hline $\begin{array}{l}\text { Article5 } \\
\text { Paragraph }(3) \\
\text { letter c }\end{array}$ & $\begin{array}{l}\text { procurement and distribution of public goods } \\
\text { whose financing is not sourced from the state } \\
\text { revenue and expenditure budget or regional } \\
\text { revenue and expenditure budget or a } \\
\text { business entity whose establishment capital } \\
\text { is partly or wholly sourced from separated } \\
\text { state assets and/or regional assets, but } \\
\text { whose availability becomes a state mission } \\
\text { as stipulated in the laws and regulations. }\end{array}$ & \multirow{2}{*}{$\begin{array}{l}\text { Freezing of } \\
\text { missions } \\
\text { and/or } \\
\text { permits } \\
\text { issued by } \\
\text { government } \\
\text { agencies. }\end{array}$} \\
\hline $\begin{array}{l}\text { Article5 } \\
\text { Paragraph (4) } \\
\text { letterc }\end{array}$ & $\begin{array}{l}\text { the provision of public services whose } \\
\text { financing is not sourced from the state } \\
\text { revenue and expenditure budget or regional } \\
\text { revenue and expenditure budget or a } \\
\text { business entity whose establishment capital } \\
\text { is partly or wholly sourced from separated } \\
\text { state assets and/or regional assets, but } \\
\text { whose availability becomes a state mission } \\
\text { as stipulated in laws and regulations - } \\
\text { invitation. }\end{array}$ & \\
\hline
\end{tabular}




\begin{tabular}{|c|c|c|}
\hline $\begin{array}{ll}\text { Article } & 15 \\
\text { letter a } & \end{array}$ & compiling and setting service standards; & \\
\hline Article 26 & $\begin{array}{l}\text { Operators are prohibited from granting } \\
\text { permits and/or allowing other parties to use } \\
\text { public service facilities, infrastructure, } \\
\text { and/or facilities which result in public service } \\
\text { facilities, infrastructure and/or facilities not } \\
\text { functioning or not in accordance with their } \\
\text { designation. }\end{array}$ & \\
\hline $\begin{array}{l}\text { Article } 33 \\
\text { Paragraph (3) }\end{array}$ & $\begin{array}{l}\text { Operators are prohibited from financing } \\
\text { other activities using budget allocations } \\
\text { intended for public services. }\end{array}$ & \\
\hline $\begin{array}{l}\text { Article } 36 \\
\text { Paragraph (3) }\end{array}$ & $\begin{array}{l}\text { The Operator is obliged to follow up on the } \\
\text { results of the complaint management as } \\
\text { referred to in paragraph (2). }\end{array}$ & \\
\hline $\begin{array}{l}\text { Article54 } \\
\text { Paragraph }(10\end{array}$ & $\begin{array}{l}\text { The Operator as referred to in Article } 5 \\
\text { paragraph (3) letter c and paragraph (4) } \\
\text { letter c violating the provisions of Article } 15 \\
\text { letter a, Article 26, Article } 33 \text { paragraph (3), } \\
\text { and Article } 36 \text { paragraph (3). }\end{array}$ & $\begin{array}{l}\text { revocation } \\
\text { of permits } \\
\text { issued by } \\
\text { government } \\
\text { agencies. }\end{array}$ \\
\hline $\begin{array}{l}\text { Article } 25 \\
\text { Paragraph(1) }\end{array}$ & $\begin{array}{l}\text { The organizers and implementers are obliged } \\
\text { to manage the facilities, infrastructure, } \\
\text { and/or public service facilities in an effective, } \\
\text { efficient, transparent, accountable, and } \\
\text { sustainable manner and are responsible for } \\
\text { the maintenance and/or replacement of } \\
\text { public service facilities, infrastructure, } \\
\text { and/or facilities. }\end{array}$ & \multirow{5}{*}{$\begin{array}{l}\text { sanksi } \\
\text { pidana dan } \\
\text { denda }\end{array}$} \\
\hline $\begin{array}{l}\text { Article } 28 \\
\text { Paragraph (1) }\end{array}$ & $\begin{array}{l}\text { Operators who intend to repair facilities, } \\
\text { infrastructure, and/or public service facilities } \\
\text { are required to announce and state the } \\
\text { deadline for completing the work in a clear } \\
\text { and open manner. }\end{array}$ & \\
\hline $\begin{array}{l}\text { Article28 } \\
\text { Paragraph(4) }\end{array}$ & $\begin{array}{l}\text { The Operators and Executors who do not } \\
\text { perform the obligations as referred to in } \\
\text { paragraph (1) are declared to have } \\
\text { committed negligence. }\end{array}$ & \\
\hline $\begin{array}{l}\text { Article29 } \\
\text { Paragraph (1) }\end{array}$ & $\begin{array}{l}\text { The organizer is obliged to provide services } \\
\text { with special treatment to certain community } \\
\text { members in accordance with the laws and } \\
\text { regulations. }\end{array}$ & \\
\hline $\begin{array}{l}\text { Article } 29 \\
\text { Paragraph }(2)\end{array}$ & $\begin{array}{l}\text { Sarana, prasarana, dan/atau fasilitas } \\
\text { pelayanan publik dengan perlakuan khusus } \\
\text { sebagaimana dimaksud pada ayat (1) } \\
\text { dilarang digunakan oleh orang yang tidak } \\
\text { berhak. }\end{array}$ & \\
\hline $\begin{array}{l}\text { Article55 } \\
\text { Paragraph (1) }\end{array}$ & $\begin{array}{l}\text { The Operator or Executor who does not carry } \\
\text { out the obligations as referred to in Article } \\
25 \text { paragraph (1), Article } 28 \text { paragraph (1) } \\
\text { and paragraph (4), Article } 29 \text { paragraph (1) }\end{array}$ & $\begin{array}{l}\text { pay } \\
\text { compensatio } \\
\mathrm{n} \text { for victims } \\
\text { based on }\end{array}$ \\
\hline
\end{tabular}




\begin{tabular}{|l|l|l|}
\hline and paragraph (2) and for these actions & court \\
results in injury, permanent disability, or & decisions \\
loss of life for other parties is subject to & \\
criminal sanctions as stipulated in the \\
legislation.
\end{tabular}

The Operator or Executor who does not carry out the obligations as referred to in Article 25 paragraph (1), Article 28 paragraph (1) and paragraph (4), Article 29 paragraph (1) and paragraph (2) and for these actions results in injury, permanent disability, or loss of life for other parties is subject to criminal sanctions as stipulated in the legislation.

pay compensatio $\mathrm{n}$ for victims based court decisions

Source: The Constitution Number 25 of 2009 concerning Public Services, 2016.

The policy of imposing criminal / criminal conditions is a combination of criminal acts and criminal responsibility (mistakes), meaning that whether or not someone's actions are proven depends on whether or not the criminal acts committed are proven. If all of the conditions for imposing a sentence are met (objective and subjective conditions), then a person is sentenced to a crime. Likewise, if the objective element of the crime is not proven, then the person must be released or if one of the objective elements of the crime is not proven then he must be released from all lawsuits.

However, after conducting research and analysis related to the legal responsibility of BPN / Kakan Pertanahan officials if the certificate product is canceled / declared invalid by a court decision in the negative publication system with positive elements, it can be seen that the legal responsibility is based on Government Regulation No: 24 of 1997 concerning registration land, explicitly normative has not regulated legal responsibilities, so that if in the land registration process the BPN/Kakan Pertanahan official makes a mistake, it is not possible to be subject to any sanctions, whether administrative, criminal or civil, this is as a result because in land registration all applications for land rights on land is sourced not from the BPN / Kakan Pertanahan but comes from the applicant. Therefore, as a consequence, all evidence of land rights in the negative publication system with positive elements is not guaranteed by the state / government in this case the BPN / Kakan Pertanahan officials.

Legal responsibilities to BPN / Land Affairs Officers are regulated in general (implicit) as formulated in Article 63 Chapter III regarding sanctions which in essence if the Land Affairs Officer ignores the provisions in Government Regulation no. 24 of 1997 and other laws and regulations relating to the implementation of the duties of land registration activities are subject to administrative sanctions in accordance with the applicable laws and regulations. However, the provision for administrative sanctions does not provide space for BPN / Kakan land officials to be legally responsible for certificate products that are declared void or invalid by court decisions.

Legal responsibility that is possible can be imposed on BPN / Kakan Pertanahan officials if there are acts or acts of maladministration that are not collegial collective in nature, meaning that legal responsibility in the event of maladministration is personal responsibility, including criminal 
responsibility. While legal responsibility in relation to unlawful acts in the field of civil law, then the responsibility is institutional, but this institutional legal responsibility cannot be subject to sanctions in the civil sector, among others in the form of compensation to the right holder, the actual owner and other parties. third, because in the negative registration system as regulated in Government Regulation Number 24 of 1997 concerning Land Registration there are no normative rules that regulate it.

\section{Conclusion}

There are 3 (three) weaknesses in the Negative Publication System (positive elements) which are used as the basis for Land Registration by Government Regulation Number 24 of 1997, namely: first; the norming system contained in Articles 3 and 4 is imperative (norm imperative) while in Article 32 paragraph (2) the rule is actually open (openbaar norm) which provides an opportunity for other parties to prove that he is the real owner of the land, thus causing consequences. there are legal disputes that must be resolved through the courts; second; the norm of legal responsibility for BPN/Kakan Land Officials who make mistakes in the implementation of land registration is not regulated in a negative publication system with positive elements, so that BPN/Land Office officials are not legally responsible when a certificate of land rights is canceled or declared invalid by a court decision; and third; norms and system for imposing sanctions for Land Registration Officers (BPN officials) who make mistakes in the implementation of land registration in Government Regulation Number 24 of 1997 is not regulated. 


\section{References}

Achmad Ali, (2002). Menguak Tabir Hukum (Suatu Kajian Filosofis dan Sosiologis). Kencana Prenada Media Group.

Bachtiar Effendy, (2014). Pendaftaran Tanah di Indonesia dan Pelaksanaannya. Alumni.

Dominikus Rato, (2010). Filsafat Hukum Mencari: Memahami dan Memahami Hukum, Yogyakarta: Laksbang Pressindo.

Johnny Ibrahim. (2006). Teori dan Metode Penelitian Hukum Normatif. Bayumedia.

Kaelan, (2013). Negara Kebangsaan Pancasila, Kultutral, Historis, Filosofis, Yuridis dan Aktualisasinya. Paradigma.

Lukman Hakim, (2012). Filosofi Kewenangan Organ dan Lembaga Negara. Setara Press.

Munir Fuadi, (2011). Teori Negara Hukum Modern (Rechtstaat). Refika Aditama.

Urip Santoso, (2012). Hukum Agraria: Kajian Komprehensif. Kencana Prenadamedia Group.

Ronni Hanitijo Soemitro, (1994). Metodologi Penelitian dan Jurimetri. Ghalia Indonesia.

Safi'. (2010). Konsep Pertanggung-jawaban Perbuatan Pemerintahan sebagai Sarana Mewujudkan Good Governance di Indonesia. Jurnal Pamator: Jurnal Ilmiah Universitas Trunojoyo, 3(2), 172-178. https://doi.org/10.21107/pamator.v3i2.2416

Safitri, Fina Ayu., ALW, Lita Tyesta \& Lumbanraja, Anggita Doramia. (2020). Akibat Hukum Penggunaan Sistem Publikasi Negatif Berunsur Positif Dalam Pendaftaran Tanah Di Kota Semarang. Notarius Jurnal Studi Kenotariatan, 13(2), 788-802. https://doi.org/10.14710/nts.v13i2.31167

Sufriadi, (2014). Tanggung Jawab Jabatan Dan Tanggung Jawab Pribadi Dalam Penyelenggaraan Pemerintahan Di Indonesia, Jurnal Yuridis, 1 (1), 57-72. http://dx.doi.org/10.35586/.v1i1.141

Wulansari, Harvini., Junarto, Rochmat \& Mujiburohman, Dian Aries. (2021). Mewujudkan Sistem Pendaftaran Tanah Publikasi Positif. Riau Law Journal, 5(1), 61-74. http://dx.doi.org/10.30652/rlj.v5i1.7875

Yanis Maladi, (2012). Pendaftaran Tanah Nasional Dan Kehidupan Hukum masyarakat. Yogyakarta: Mahkota Kata.

Zairin Harahap, (1997). Hukum Acara Peradilan Tata Usaha Negara, Jakarta: Raja Grafindo Persada. 